Oláh, J., Karmazin, Gy., Máté, D., Grabara, J. K., Popp, J. (2017). The effect of acquisition moves on income, pre-tax profits and future strategy of logistics firms. Journal of International Studies, 10(4), 233-245. doi: 10.14254/2071$8330.2017 / 10-4 / 18$

\title{
The effect of acquisition moves on income, pre-tax profits and future strategy of logistics firms
}

\section{Judit Oláh}

Institute of Applied Informatics and Logistics, Faculty of Economics

and Business, University of Debrecen, Hungary

olah.judit@econ.unideb.bu

\section{György Karmazin}

Department of Commerce, Marketing and International Business,

College of Szolnok, University of Pallasz. Athéné, Hungary

gyorgy.karmazin@gmail.com

\section{Domicián Máté}

Institute of Accounting and Finance, Faculty of Economics and

Business, University of Debrecen, Hungary

mate.domician@econ.unideb.bu

\section{Janusz K. Grabara}

Faculty of Management, Czestochowa University of Technology, Poland grabara@zim.pcæ.pl

\section{József Popp}

Institute of Sectoral Economics and Methodology, Faculty of Economics

and Business, University of Debrecen, Hungary

popp.jozsef@econ.unideb.bu

Abstract. Our research deals with a comprehensive study of the management success factors of logistics service providers using a new approach, and examines the life of logistics service companies. The data were collected from 51 logistics service providers in Hungary. We searched for the proper enterprise scale - acquisitions - strategies (including the method of looking for the economies of scale in the LSP segment to be examined, and the role of strategy choice). Our research has found that among logistics companies those firms which followed the growth pattern has significantly higher sales revenue than

Received: May, 2017 1st Revision: August, 2017 Accepted: November, 2017 8330.201 the companies growing organically. Additionally, logistics companies considering their pre-tax profits - work more efficiently when they have a growth strategy (regardless of its time lag). However, this claim is true only for those companies that did not have any (revenue) growth over the previous 
period. The results of our research can effectively help logistics service providers find their business success factors, which will enable them fulfil the expectations of their customers in the supply chain better.

Keywords: logistics service providers, collaboration, relationship value, competitiveness.

JEL Classification: L25, M21, M51

\section{INTRODUCTION}

In the recent years it has become increasingly relevant to examine logistics as a field of science that significantly influences the value creation process and competitiveness of enterprises, and more specifically, to analyse activities of the enterprises providing logistics services. In order to achieve these aims, it necessary to identify the management success factors supporting the fundamental competitiveness of logistics enterprises, as this is an essential development step for all the companies involved (Wu, 2012).

The logistics services industry has been exhibiting tremendous growth for more than two decades already (Maloni \& Carter, 2006), and the work of LSPs has been increasingly recognised during the last few years, as being significant for the functioning supply relationships (Huemer, 2012).

A more advanced role for LSPs has been created by the connectivity and communication requirements of the leading supply chain. Logistics service providers strive to boost their capabilities and use their resources efficiently. As the global economy has expanded, logistics has become increasingly important parallel to the expanding role of logistics service providers. In order to identify their management success factors it is certainly justified to carry out a comprehensive research among logistics service providers. The role of this service providers has become increasingly important in the economy. For global logistics service companies, international supply chains pose challenges and opportunities at the same time. The search for proper enterprise size with acquisitions and strategies (such as the search for economies of scale of the logistics service providers, the role of strategic choice) can support logistics service companies in identifying their management success factors which could assist them in meeting the expectations of their customers in the value chain.

\section{LITERATURE REVIEW}

\subsection{Key success factors and performance}

Literature shows that the logistics services industry is an increasingly important topic for researchers (Maloni \& Carter, 2006; Selviaridis \& Spring, 2007; Trentin, 2011; Yeung, Selen, Sum, \& Huo, 2006). The most frequent references to the topic since the 1990s have been mostly American and British, but researchers from North European countries such as Sweden and Norway have also been publishing their scientific findings related to the sector since the turn of millennium (Hertz \& Alfredsson, 2003; Huemer, 2012; Lukassen \& Wallenburg, 2010; Markides \& Holweg, 2006; Murphy \& Daley, 2001).

Many LSPs have taken initiatives to broaden the scope of their services in order to satisfy fully the increasing requirements of customers for one-stop services (Murphy \& Daley, 2001). A major decision concerns the extent to which they should improve their service performance and expand their service capability (Lai \& Cheng, 2003). Performance measurement is an important approach in the logistics service supply chain (LSSC), which can improve the competitiveness of the overall supply chain. The 
complicated measurement system includes various quantitative and qualitative indices with undefined problems (Gong \& Yan, 2015). Several key success factors have been proposed in the 3PL literature to judge performance. Examples include long-term relationships and building a history of favourable experiences (La Londe \& Powers, 1993). After adopting a general service firm's perspective on studying LSPs, Berglund (2000) identified four LSP value creation modes with associated value drivers, namely: operational efficiency, integration of customer operations, supply chain management and integration, and vertical or horizontal network development. (Busse \& Wallenburg, 2014) noted that collaboration is an important value creation mode. (Liu, Grant, McKinnon, \& Feng, 2010) developed and empirically examined 13 firm-specific capability constructs based on a survey of Chinese LSPs by drawing on work from economics and strategy on firm-level competitiveness, particularly the resource-based view. In this study, networking factors include IT, service networks and marketing; strategic factors include corporate culture, innovation, strategic management and human resource management; and operational factors include service quality, customer relationship management, operations management, inventory management, business process management and cost management. The business performance of a LSP and distribution centre (DC) is significantly affected by operational efficiency (Huo \& Zhao, 2015, Ślusarczyk, 2017).

The identification of the management success factors supporting the fundamental abilities of the competitiveness of Hungarian logistics enterprises (Figure 1) is an essential step in the development of the enterprises in the target group.

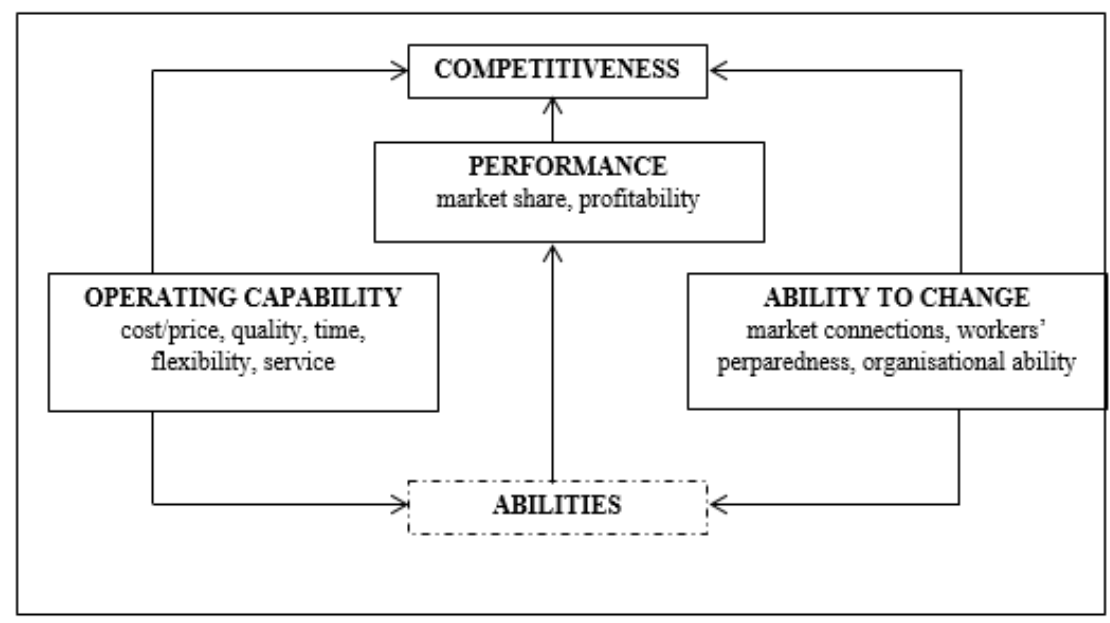

Figure 1. Enterprise competitiveness model

Source: based on (Chikán, 2013)

The competitiveness of enterprises is determined by their operating capability, their ability to change and their performance. This correlation is illustrated by Figure 1 . The ability to change and flexibility have a significant role in the competitiveness model.

Current Hungarian and international social, economic and political impacts, changes and trends were explored in order to lay the foundations of the research. In addition, this paper established the groups of success factors based on the observations made, and the conclusions drawn from discussions with the managers of various Hungarian LSP enterprises, as well as the results of meetings with professional academics (Figure 2). Furthermore, this research was established by using these bases and by looking for correlations between abilities and 'success factors', as well as by grouping the various factors, such as: 
1. Trust - degree of success - flexibility (trust refers to the examination of the fundamental factor of relations within a given enterprise and also between cooperating enterprises, looking for the role of the manager in establishing a trustful atmosphere).

2. Time - service portfolio - flexibility (time-based competition of products and services, supply chains, the composition and profitability of the service portfolio).

3. Searching for the proper enterprise scale - acquisitions - strategies (including the method of searching for economies of scale (market) in the LSP segment to be examined, the role of choosing a strategy).

4. The correlation between the degree of integration of LSPs in the supply chain - the impact of (special) IT solutions and developments - and flexibility, as well as its impact on the financial results of the enterprise.

CHANGES

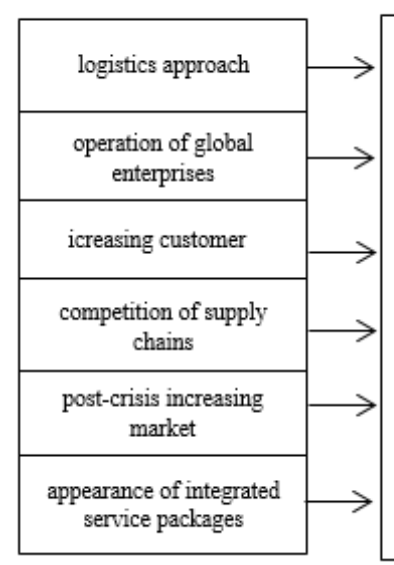

ABILITIES

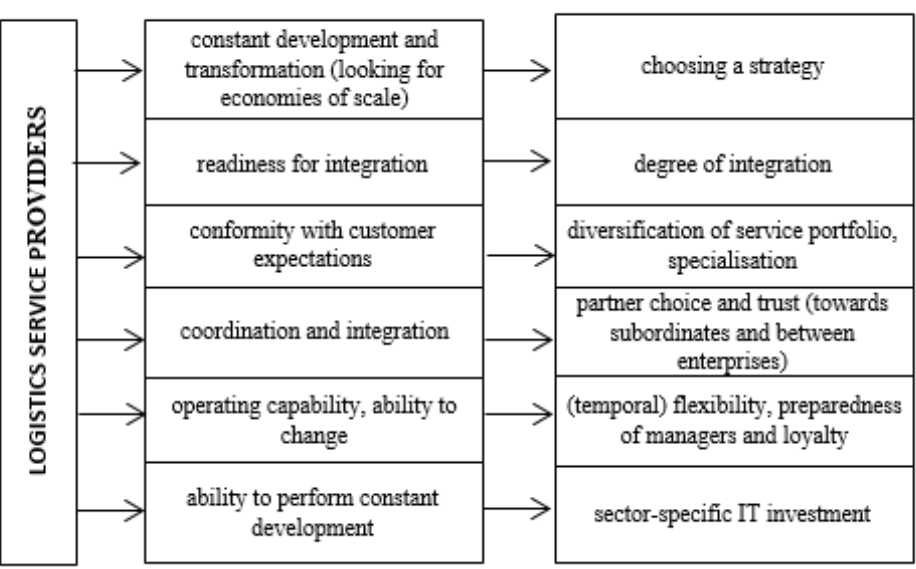

Figure 2. Forces acting on LSPs and the abilities needed for their competitiveness in the recent period (while considering the success factors which are related to performance and degree of success)

Source: Authors' own research, 2016

The development of companies has two distinct paths: one is organic (internal, growing on the basis of the company's knowledge base) and the other is growth through acquisition (with the incorporation of other companies). Further concentrations are expected among logistics service providers, primarily because of the search for economies of scale, so it is advisable when formulating the hypothesis of the research among logistics service providers to look particularly at the management and profitability of the acquisition growth steps (income and pre-tax profit).

In formulating the hypotheses, the key success factors for developing management need to be taken into account, and their impact and their relationship analysed in terms of the competitiveness of the logistics service companies (including disaggregating them separately according to their performance, and their capacity to operate and change). The following hypotheses have been formulated in the factors "searching for the proper enterprise scale - acquisitions - strategies" (including the method of looking for economies of scale (market) of the LSP segment to be examined, the role of choosing a strategy)".

Hypothesis 1: Growth through acquisitions (economies of scale) better supports the growth of logistical service providers' income and pre-tax profits than organic growth.

Hypothesis 2: The medium-term, growth-committed strategy is more conducive to the growth of pre-tax profitability of logistics service providers than other strategies. 


\subsection{Diversification of the service portfolio}

The categorization of logistic services began in the early 1990s when complex logistics functions and services were developed within the framework of long-term partnerships within traditional transport and warehousing activities. This phenomenon is called 3 PL (Third Party Logistics). These services are provided by the 3rd Party Logistics Provider (3 PLP). In international literature, the growing level of logistics services is represented as a pyramid (Trembeczky, 2007). In addition to the pyramid, the everdeepening integration of logistics service providers into the supply chain is evident. Due to the integration and the increasing customer service expectations, the number of services provided by the logistics service provider is increasing and the service portfolio is widening.

The development and change of logistics service providers was shown by (Meng, Liang, Lin, \& Chen, 2010). We can observe that the logistics company is becoming an increasingly complex service provider in the supply chain and is increasingly integrated into the business processes of its clients. According to van der Veeken \& Rutten (1998), the market environment of a logistics enterprise should be decisive in the company's approach to logistics services. They describe three choices in their article. Firstly, a unified service for all customers, where the business can benefit from economies of scale, providing the same service to all its customers. Secondly, a customized logistics service, where individual customer needs show great variation and, thirdly, differentiated logistic services, where differentiated logistic services can be provided for different customer groups. (Panayides, 2004) investigated the relationship between the logistics service provider and the client and concluded that the relationship between the customer and the logistics service provider - in addition to influencing the logistical provider's entry strategy - promotes key organizational capabilities, such as organizational learning and innovation, in a positive direction, facilitating the efficiency and performance of the supply chain.

One way of creating value-added services is to develop specialized competences (e.g. knowledge of geographic or specialized product delivery, etc.). Another possibility is that the freight forwarder provides ever-wider logistic services, primarily as a result of corporate acquisitions and mergers, and thus becomes able to become a logistics service provider and to provide and present everything in one place (Murphy \& Daley, 2001). Based on this research, (Lemoine \& Dagnæs, 2003) found that at the beginning of the new millennium, the companies investigated moved towards a unified global strategy aimed at becoming a global logistics service provider. The strategy involved the integration of complexity, hub-and-spoke infrastructure, integration of companies within the network and access to shared ICT (information communication technology). (Bagchi \& Skjoett-Larsen, 2003) examines two dimensions of integration into supply chains: from an IT integration and an organizational integration perspective. IT investments will remain important in the future and the introduction and leveraging the best technologies may yield competitive advantages and higher financial rewards for LSPs (Oláh, Karmazin, Pető, \& Popp, 2017; Gwiazda, et all., 2015).

The process of becoming a logistics service provider, whatever the main business activity may be, leads in one branch, through specialization to logistics networks and co-operation. Meanwhile in another branch, via diversification of services (Murphy \& Daley, 2001; Markides \& Holweg, 2006) and complexity and - thanks to possible acquisitions (Wong \& Karia, 2010; Walancik \& Chmiel, 2014) and mergers - to the 3 PL form (or through this to an even more advanced form). Moreover, economic and social benefits and the effects of virtual enterprises for customers and production companies and service providers are essential for virtual enterprises, see (Kovács \& Kot, 2017) and (Zielińska, Prudzienica, Mukhtar, \& Mukhtarova, 2016). 


\section{METHODOLOGY}

A list of around 300 Hungarian LSPs was compiled from information provided by the professional organisations contacted by us before starting the research, as well as official sources which can be accessed in the trade press. From this list the target group was selected, including enterprises with revenue (net sales) of at least EUR 100 thousand, but not higher than EUR 100 million per year. This group consisted of 284 LSP enterprises. The survey was carried out by the GFK Hungary, Market Research Institute.

Thirteen per cent of the LSPs interviewed were established in 1990, when several entrepreneurs decided to set up their own companies due to the political and economic restructuring. 36 of the 56 enterprises examined were founded with international road transport as their activity. More than $50 \%$ of the examined LSPs were engaged in domestic road and international road transport of goods or road forwarding services directly after their establishment. Thirty-two per cent of the newly-established LSPs were primarily involved in warehousing activities. The following activities ranged between $10 \%$ and $20 \%$ : railway transport and/or forwarding, air freight and/or forwarding, water freight and/or forwarding, transport and/or forwarding of containers, custom-house agent activities, transport and/or forwarding of oversized goods, logistics activities outsourced by clients inside or outside the factory yard, freight insurance and logistics consultancy. Seventy-five per cent of the enterprises involved in the research were primarily Hungarian-owned.

The geographical distribution was drawn up to illustrate the basic and sample population of the research data, showing the regional location of the Hungarian logistics enterprises based on the available data for the purpose of providing representativeness. The regional locations categorised into two NUTS 3 counties properly show the 'identity' of distributions and verify representativeness. Also, representativeness is further confirmed by the test results of the basic and sample populations of the research data obtained, as well as the similarity of the histograms illustrating distributions. The test results obtained led us to conclude that neither of the two distributions are normal ( $p<0.001$ in both cases) and that the two distributions are very similar indeed, based on the parameters examined. Furthermore, neither the sample-based, nor the population-based distribution can be regarded as normal (their parameters differ), but the graphic draft shows that the pointedness of both distributions are similar, bending to the left and stretching to the right. Accordingly, we conclude that the curves of both the examined population and the sample are similar to each other (even though they deviate from the normal curve). F test statistics further verify similarity, since the variance of the two variables can be regarded as similar $(F=2.213$; $p$ $=0.138)$.

A 51-question questionnaire was put together for the target group to confirm or reject our research questions. We pre-tested the questionnaire in ten companies, which were representative of the different environments present in the sampled population. The main objective of this pre-test was to verify the appropriateness of the questionnaire. Hence, we assessed the difficulties faced by the respondents in understanding the questions, and in retrieving the required quantitative information as well as uncovering eventual ambiguities in our questions.

The net revenue and earnings before tax of all 51 responding LSPs for the period between 2004 and 2011 were used to examine our research hypotheses. The total revenue of the respondents was 456 million EUR in 2011, a year for which reliable statistical data were available. This value is more than $50 \%$ of the cumulated annual revenue of all Hungarian logistics enterprises in 2012. Considering the $20 \%$ response rate and the revenue data exceeding $50 \%$, the representativeness of our research can be confirmed. 


\section{EMPIRICAL RESULTS AND DISCUSSION}

The H1 hypotheses were justified using the results of the empirical research. The results of the research that led to the development of the logistics service providers, the appearance of their categories and their characteristics, as well as the substantiation of the established hypotheses, brought further novel scientific findings. To justify this hypothesis, we used the data for the net sales revenue of the companies (ENA) and their pre-tax profit (AEE). To confirm the hypothesis, it is first necessary to look at whether there is a significant difference between a company's pre-tax profit (AEE) - for growthproducing and non-producing companies - if they have acquired other firms, and if they have not (hereafter, different categories) (Table 1).

Table 1

Average pre-tax profit of companies in different categories (million HUF / company)

\begin{tabular}{|l|c|c|}
\hline & Already acquired other firms & Not acquired other firms \\
\hline Produced growth & 56.23 & 53.10 \\
\hline Did not produce growth & 55.07 & 45.17 \\
\hline
\end{tabular}

Source: authors' own research

Table 1 shows that there is no significant difference in the average pre-tax results of logistic companies when considering companies that produce organic growth (45.17 - 53.10 million HUF / company) and companies that have grown through the acquisition (55.07 - 56.23 million HUF / company).

If we do the same survey taking into account the average net revenues, we find significant differences in the figures ${ }^{1}$ (Table 2).

Table 2

Net sales of average sales of companies in different categories (million HUF / company)

\begin{tabular}{|l|c|c|}
\hline & Already acquired other firms & Not acquired other firms \\
\hline Produced growth & 2869 & 1129 \\
\hline Did not produce growth & 967 & 1346 \\
\hline
\end{tabular}

Source: authors' own research

To be convinced that these differences are significant, we need to analyse t-tests. Firstly, we also need to examine whether the variances in each category are the same or different. In the four dimensions of the average, there is only a significant difference between 2869 and 967 . We will test whether there is a significant difference in terms of net sales revenue (ENA) between growth-producing companies and companies which do not produce growth but carry out acquisitions. From the t-test table (Table 3) it can be seen that on the basis of the Levene test we can assume similar variances in subgroups. Thus, the t-test 1 Three outliers were discarded from the sample; their revenue significantly distorted the results of the examination (elements 13 ,
$18,45)$. 
accepts at the 0.070 significance level ${ }^{2}$ the hypothesis that there is a significant difference in the case of acquiring companies between the average net sales revenue of the growing (2869 million HUF / company) and the average net sales revenue of the non-growing company ( 967 million HUF / company).

Table 3

The results of the independent sample t-test (based on HP 1)

\begin{tabular}{|c|c|c|c|c|c|c|c|c|c|c|}
\hline & \multicolumn{2}{|c|}{$\begin{array}{l}\text { Levene test } \\
\text { for the } \\
\text { equivalence } \\
\text { of variances }\end{array}$} & \multicolumn{7}{|c|}{ T-test to match the averages } \\
\hline & & \multirow[t]{2}{*}{$\mathbf{F}$} & \multirow[t]{2}{*}{ Sig. } & \multirow[t]{2}{*}{$\mathbf{t}$} & \multirow[t]{2}{*}{ df } & \multirow[t]{2}{*}{ Sig. (bil.) } & \multirow[t]{2}{*}{$\begin{array}{l}\text { Avg. } \\
\text { difference }\end{array}$} & \multirow{2}{*}{$\begin{array}{l}\text { Standard } \\
\text { error } \\
\text { difference }\end{array}$} & \multicolumn{2}{|c|}{$\begin{array}{c}\text { Differences at } 95 \% \\
\text { confidence } \\
\text { intervals }\end{array}$} \\
\hline & & & & & & & & & lower & upper \\
\hline \multirow{2}{*}{$\begin{array}{l}\text { ENA } \\
\text { (million } \\
\text { HUF) }\end{array}$} & $\begin{array}{l}\text { Assuming } \\
\text { equivalent } \\
\text { variances }\end{array}$ & \multirow[b]{2}{*}{1.815} & \multirow[b]{2}{*}{0.227} & 2.205 & 6.000 & 0.070 & 1901.895 & 862.709 & -209.078 & 4012.867 \\
\hline & $\begin{array}{l}\text { Not } \\
\text { assuming } \\
\text { equivalent } \\
\text { variances }\end{array}$ & & & 2.844 & 4.744 & 0.038 & 1901.895 & 668.626 & 154.873 & 3648.917 \\
\hline
\end{tabular}

Source: authors' own research

We compared the average net sales revenue of organic (HUF 1129 million / company) and acquisition (2869 million HUF / company) growth companies. Before performing a t-test, in this case we also have to decide on the two categories of variance, i.e. whether it is homogeneous or heterogeneous. They do not agree on the basis of the Levene test. Accordingly, the t-test accepts our hypothesis that there is a difference between the net sales revenue of organic companies (ENA) and the net sales revenue of the post-acquisition companies (ENA): acquiring companies have achieved significantly better results (sig.:0.014) (Table 4).

Table 4

The results of the independent sample t-test (based on HP 1)

\begin{tabular}{|c|c|c|c|c|c|c|c|c|c|c|}
\hline & & \multicolumn{2}{|c|}{$\begin{array}{c}\begin{array}{c}\text { Levene test } \\
\text { for the }\end{array} \\
\text { equivalence } \\
\text { of variances }\end{array}$} & \multicolumn{7}{|c|}{ T-test to match the averages } \\
\hline & & \multirow[t]{2}{*}{$\mathbf{F}$} & \multirow[t]{2}{*}{ Sig. } & \multirow[t]{2}{*}{$\mathbf{t}$} & \multirow[t]{2}{*}{ df } & \multirow[t]{2}{*}{ Sig. (bil.) } & \multirow[t]{2}{*}{$\begin{array}{l}\text { Avg. } \\
\text { difference }\end{array}$} & \multirow{2}{*}{$\begin{array}{l}\text { Standard } \\
\text { error } \\
\text { difference }\end{array}$} & \multicolumn{2}{|c|}{$\begin{array}{c}\text { Differences at } 95 \% \\
\text { confidence } \\
\text { intervals }\end{array}$} \\
\hline & & & & & & & & & lower & upper \\
\hline \multirow{2}{*}{$\begin{array}{l}\text { ENA } \\
\text { (million } \\
\text { HUF) }\end{array}$} & $\begin{array}{l}\text { Assuming } \\
\text { equivalent } \\
\text { variances }\end{array}$ & \multirow{2}{*}{0.040} & \multirow{2}{*}{0.843} & -2.702 & 20 & 0.014 & -1740.502 & 644.071 & -3084.011 & -396.993 \\
\hline & \begin{tabular}{|l|} 
Not assuming \\
equivalent \\
variances
\end{tabular} & & & -2.475 & 5.850 & 0.049 & -1740.502 & 703.161 & -3471.823 & -9.182 \\
\hline
\end{tabular}

Source: authors' own research

\footnotetext{
2 Although the level of significance value only minimally exceeds the generally desired value of 0.05 , it can be heuristically
} accepted (instead of a 95\% level of certainty, we will express the conclusion with a $93 \%$ level of certainty). 
Based on the above tests, it seems that we can clearly distinguish the net sales of companies which, although they have been growing, have not grown as the result of acquisitions (organic growth) and results for those that have carried out acquisitions. The above calculations were also performed for pre-tax profits per employee, but there are no significant differences (the levels of significance of the t-tests showed levels far greater than 0.05). Taking into account the above calculations and test results, we can formulate the thesis as follows.

In our research, we have found the following thesis 1: Among logistics companies those that follow a growth model have significantly higher revenue than those that grow organically.

The "road leading" to the thesis and the results of the attached calculations can offer significant support to leading logistics specialists in their decisions, especially in the field of alternative methods of development strategies, and the selection and application of these methods.

The strategic time lag variable derives from question B25. This is a category variable, from which the 'mid-term' and 'non-medium-term' cases have to be filtered. The growth strategy was identified from variable B27. There is also a need to filter the growth and non-growth strategies. The test variable uses the value of the pre-tax profits and filters the individuals using the results variable (increased or decreased).

Table 5

Average pre-tax profits in individual categories (million HUF/firm)

\begin{tabular}{|l|c|c|}
\hline & With a growth strategy & Without a growth strategy \\
\hline Produced growth & 45.2 & -17.59 \\
\hline Did not produce growth & 60.7 & -8.01 \\
\hline
\end{tabular}

Source: authors' own research

It can be seen from the statistics, in Table 5, that there are significant differences between the results of companies that operate according to a growth strategy and a non-growth strategy. However, t-tests have to be carried out to assess the degree of difference (produced growth / did not produce growth categories were established on the basis of net sales revenue (ENA) variable). The results of the t-test show that the variance of each category is the same, so the t-test significantly rejects the finding that these results differ (sig: 0.261) in the produced growth category (Table 6). In summary, we can claim that the results are not significantly different in each test category.

Table 6

The results of the independent sample t-test (based on HP 2) 1

\begin{tabular}{|c|c|c|c|c|c|c|c|c|c|c|}
\hline & & \multicolumn{2}{|c|}{$\begin{array}{c}\text { Levene test for } \\
\text { the equivalence } \\
\text { of variances }\end{array}$} & \multicolumn{7}{|c|}{ T-test to match the averages } \\
\hline & & \multirow[t]{2}{*}{$\mathbf{F}$} & \multirow[t]{2}{*}{ Sig. } & \multirow[t]{2}{*}{$t$} & \multirow[t]{2}{*}{ df } & \multirow{2}{*}{$\begin{array}{l}\text { Sig. } \\
\text { (bil.) }\end{array}$} & \multirow{2}{*}{$\begin{array}{c}\text { Avg. } \\
\text { difference }\end{array}$} & \multirow{2}{*}{$\begin{array}{c}\text { Standard } \\
\text { error } \\
\text { difference }\end{array}$} & \multicolumn{2}{|c|}{$\begin{array}{l}\text { Differences at } 95 \% \\
\text { confidence intervals }\end{array}$} \\
\hline & & & & & & & & & lower & upper \\
\hline \multirow{2}{*}{$\begin{array}{l}\text { AEE_ } \\
\text { 2011, } \\
\text { Million } \\
\text { HUF }\end{array}$} & $\begin{array}{l}\text { Assuming } \\
\text { equivalent } \\
\text { variances } \\
\end{array}$ & 1.136 & 0.298 & 1.153 & 23 & 0.261 & 62.825 & 54.479 & -49.874 & 175.523 \\
\hline & $\begin{array}{l}\text { Not assuming } \\
\text { equivalent } \\
\text { variances }\end{array}$ & & & 2.195 & 22.691 & 0.039 & 62.825 & 28.622 & 3.571 & 122.078 \\
\hline
\end{tabular}

Source: authors' own research 
We get another result by checking the test for the 'no-growth' category. In this case, the variances in each group differ and the t-test significantly justifies the difference in average results (sig. 0.012) (Table 7).

Table 7

The results of the independent sample t-test (based on HP 2)

\begin{tabular}{|c|c|c|c|c|c|c|c|c|c|c|}
\hline & \multicolumn{2}{|c|}{$\begin{array}{c}\text { Levene test for } \\
\text { the equivalence } \\
\text { of variances }\end{array}$} & \multicolumn{7}{|c|}{ T-test to match the averages } \\
\hline & & \multirow[t]{2}{*}{$\mathbf{F}$} & \multirow[t]{2}{*}{ Sig. } & \multirow[t]{2}{*}{ t } & \multirow[t]{2}{*}{ df } & \multirow[t]{2}{*}{$\begin{array}{l}\text { Sig. } \\
\text { (bil.) }\end{array}$} & \multirow[t]{2}{*}{$\begin{array}{c}\text { Avg } \\
\text { difference }\end{array}$} & \multirow[t]{2}{*}{$\begin{array}{l}\text { Standard } \\
\text { error } \\
\text { difference }\end{array}$} & \multicolumn{2}{|c|}{$\begin{array}{c}\text { Differences at } 95 \% \\
\text { confidence } \\
\text { intervals }\end{array}$} \\
\hline & & & & & & & & & lower & upper \\
\hline \multirow{2}{*}{$\begin{array}{l}\text { AEE_- } \\
2011, \\
\text { Million } \\
\text { HUF }\end{array}$} & $\begin{array}{l}\text { Assuming } \\
\text { equivalent } \\
\text { variances }\end{array}$ & 5.037 & 0.036 & 2.554 & 21 & 0.018 & 68.693 & 26.896 & 12.760 & 124.626 \\
\hline & $\begin{array}{l}\text { Not assuming } \\
\text { equivalent } \\
\text { variances }\end{array}$ & & & 2.819 & 16.570 & 0.012 & 68.693 & 24.368 & 17.179 & 120.207 \\
\hline
\end{tabular}

Source: authors' own research

However, the above average results are independent of the strategic time constraints of companies (for t-sig: 0.230 for growth companies, t-sig: 0.093 for non-growers). As a conclusion, regarding the above calculations, we can claim that, taking into account the growth dynamics of companies, there is a significant relationship between the pre-tax profits of the companies surveyed and their commitment to growth (as expressed in their strategy).

During our research, we have identified the following thesis 2: Logistics companies - considering their pre-tax profits - work more effectively when they have a growth strategy (regardless of the time horizon). However, this claim is true only for companies that did not grow (in revenue terms) over the previous period. Overall, a time-independent growth strategy developed by the leaders of Hungarian logistics companies results in a more profitable company.

A growing number of studies deal with effective ways to increase the production activity and capacity, connected with the reduction of the costs of maintaining (Kaczmarek J, 2014) and enhancing logistics community (Grondys K, Kott I, \& Wiśniewska-Sałek A, 2014) in the scope of logistics. Anyway, in order to expand the sales of logistics enterprises, in our opinion, one of the best strategies is to support acquisition with financing their trade transactions.

One of the main limitations of our study is that other important factors that effects on financial acquisition, such as the features of procurement process of logistic enterprises etc., are not included in our models, due to the restricted access to data. Moreover, this pilot research was conducted within one research perspective, so these findings have a limited generalisability. Nevertheless, our further research can access to investigating acquisition by additional enterprise groups. Moreover, we expect to implement further analysis in the coming years to explore and expand the extent to which other determinants may explain and make comparable them in different branches.

\section{CONCLUSION}

The research results and theses related to Hypotheses 1 and 2 provide significant new information for managers of logistics companies to help develop good business strategies and future market ambitions. 
Among the alternative methods of development strategies, hypothesis 1 examines the effectiveness of acquisition, paralleling it with the organic growth strategy.

Theses 1: Among logistics companies, those firms following the acquisition growth pattern achieve significantly higher revenue than companies with an organic growth strategy do. As a conclusion, if the development goal of a logistics company is clearly to increase revenue, then this can best be achieved by acquisitions. This is not true for pre-tax profits. Therefore, there is a price to pay for growth; whether the company grows by acquisitions or by organic growth, it needs to be financed (mostly from the profits produced). As a result of discussions with leading experts in logistics, we can state that the market increase of logistics orders generated by production / manufacturing and trading companies will determine the future pace of the concentration of the Hungarian logistics market, which will also affect the market balance between organic and acquisition based strategies. As a suggestion, for logistics service providers, if, by virtue of their organic growth, they grow better than the market average, $5-7 \%$, then it is worth keeping this strategy (as it has lower risk). Conversely, if the management decides on a below average performance and/or a more intense growth strategy, and/or because of customer expectations they may need to open new markets or offer new services, they may want to get involved in acquisitions for further development, after proper preparation. It is recommended that these acquisitions be prepared and carried out with the help of an external expert company. Hypothesis 2 explores the success of the medium-term, growth-committed strategy.

Theses 2: Logistics companies operate more effectively if they have a growth strategy (regardless of the time lag). However, this claim is true only for companies that have not been able to grow (in revenue) over the previous period. That is, the time-independent growth strategy developed by the leaders of logistic companies leads to a more profitable company. As a conclusion, we can also claim that the development and adoption of a growth strategy within a corporate organization already has the power of a 'self-fulfilling prediction'. for example, both employees and leaders believe in growth and want to achieve it together (regardless of its time lag), and so this approach (in whole or in part) is more profitable than in the case of those companies, which do not believe in growth, or have no growth strategy. As a suggestion, it is recommended that logistics companies should develop and follow a realistic growth and tax harmonization strategies, as declared by Sosnowski (2014). The implementation of this strategy, as a consequence of the above research and literature findings, will continue to allow more profitable operation in the future, too.

\section{ACKNOWLEDGEMENT}

Supported by the ÚNKP-17-4 New National Excellence Program of the Ministry of Human Capacities.

\section{REFERENCES}

Bagchi, P. K., \& Skjoett- Larsen, T. (2003). Integration of Information Technology and Organizations in a Supply Chain. The International Journal of Logistics Management, 14(1), 89-108. https://doi.org/10.1108/09574090310806477

Busse, C., \& Wallenburg, C. M. (2014). Firm-level innovation management at logistics service providers: an exploration. International Journal of Logistics Research and Applications, 17(5), 396-419. https://doi.org/10.1080/13675567.2013.871509

Chikán, A. (2013). Mitôl versenyképes egy vállalat? Versenyképes vállalat = versenyképes gazdaság. In - (Ed.). Budapest: Világgazdaság. Retrieved from https://www.vg.hu/konferencia/versenykepes-vallalatversenykepes-gazdasag-410641/

Gong, K., \& Yan, H. (2015). Performance Measurement of Logistics Service Supply Chain Using Bijective Soft Set. Journal of Advanced Manufacturing Systems, 14(1), 23-40. https://doi.org/10.1142/S0219686715500031 
Grondys K, Kott I, \& Wiśniewska-Sałek A. (2014). Entrepreneurship as an opportunity of development for Industrial Companies using Logistics centers. Polish Journal of Management Studies, 10, 45-53.

Gwiazda, A., Monica, Z., \& Czekanski, A. (2015). Application of the advanced engineering systems for modeling logistics processes. Forum Scientiae Oeconomia, 3(2), 81-93.

Hertz, S., \& Alfredsson, M. (2003). Strategic development of third party logistics providers. Industrial Marketing Management, 32(2), 139-149. https://doi.org/10.1016/S0019-8501(02)00228-6

Huemer, L. (2012). Unchained from the chain: Supply management from a logistics service provider perspective. Journal of Business Research, 65(2), 258-264. https://doi.org/10.1016/J.JBUSRES.2011.05.028

Huo, B., \& Zhao, X. (2015). The impacts of trust and contracts on opportunism in the 3PL industry: The moderating role of demand uncertainty. International Journal of Production Economics, 170, 160-170. https://doi.org/10.1016/J.IJPE.2015.09.018

Kaczmarek J. (2014). Measurement of Creating Corporate Value for Shareholders - Development of Measurements and Improvement of Management Competence and Skills. Polish Journal of Management Studies, 9, 73-82.

Kovács, G., \& Kot, S. (2017). Economic and social effects of novel supply chain concepts and virtual enterprises. Journal of International Studies, 10(1), 237-254. https://doi.org/10.14254/2071-8330.2017/10-1/17

La Londe, B. J., \& Powers, R. F. (1993). Disintegration and Re- Integration: Logistics of the Twenty- First Century. The International Journal of Logistics Management, 4(2), 1-12. https://doi.org/10.1108/09574099310804948

Lai, K.-H., \& Cheng, T. C. E. (2003). Supply chain performance in transport logistics: An assessment by service providers. International Journal of Logistics Research and Applications, 6(3), 151-164. https://doi.org/10.1080/367556031000123115

Lemoine, W., \& Dagnæs, L. (2003). Globalisation strategies and business organisation of a network of logistics service providers. International Journal of Physical Distribution \& Logistics Management, 33(3), 209-228. https://doi.org/10.1108/09600030310471961

Liu, X., Grant, D. B., McKinnon, A. C., \& Feng, Y. (2010). An empirical examination of the contribution of capabilities to the competitiveness of logistics service providers. International Journal of Physical Distribution \& Logistics Management, 40(10), 847-866. https://doi.org/10.1108/09600031011093232

Lukassen, P. J. H., \& Wallenburg, C. M. (2010). Pricing Third-Party Logistics Services: Integrating Insights from the Logistics and Industrial Services Literature. Transportation Journal. Penn State University Press. https://doi.org/10.2307/40904872

Maloni, M. J., \& Carter, C. R. (2006). Opportunities for Research in Third-Party Logistics. Transportation Journal. Penn State University Press. https://doi.org/10.2307/20713632

Markides, V., \& Holweg, M. (2006). On the diversification of international freight forwarders. International Journal of Physical Distribution \& Logistics Management, 36(5), 336-359. https://doi.org/10.1108/09600030610676231

Meng, S.-M., Liang, G.-S., Lin, K., \& Chen, S.-Y. (2010). Criteria for services of air cargo logistics providers: How do they relate to client satisfaction? Journal of Air Transport Management, 16(5), 284-286. https://doi.org/10.1016/J.JAIRTRAMAN.2010.02.003

Murphy, P. R., \& Daley, J. M. (2001). Profiling international freight forwarders: an update. International Journal of Physical Distribution \& Logistics Management, 31(3), 152-168. https:// doi.org/10.1108/09600030110389433

Oláh, J., Karmazin, G., Pető, K., \& Popp, J. (2017). Information technology developments of logistics service providers in Hungary. International Journal of Logistics Research and Applications, 1-13. https://doi.org/10.1080/13675567.2017.1393506

Panayides, P. M. (2004). Logistics service providers: An empirical study of marketing strategies and company performance. International Journal of Logistics Research and Applications, 7(1), 1-15. https://doi.org/10.1080/13675560310001619231

Selviaridis, K., \& Spring, M. (2007). Third party logistics: a literature review and research agenda. The International Journal of Logistics Management, 18(1), 125-150. https://doi.org/10.1108/09574090710748207

Sosnowski, M. (2014). Dilemmas of tax-inducted location decisions. Journal of International Studies, 7(2), 83-95. https://doi.org/10.14254/2071-8330.2014/7-2/7

Ślusarczyk, B. (2017) Prospects for the shared services centers development in Poland in the context of human resources availability, Polish Journal of Management Studies, $15 \quad$ (1), 218-231. https://doi.org/10.17512/pims.2017.15.1.21

Trembeczky, L. (2007). Az outsourcing müködése, lehetöségeinek kihasználása a Honvédelmi Minisztérium - Magyar Honvédség gazdaságosabb ellátása érdekében. Zrínyi Miklós Nemzetvédelmi Egyetem.

Trentin, A. (2011). Third-party logistics providers offering form postponement services: value propositions and organisational approaches. International Journal of Production Research, 49(6), 1685-1712. https://doi.org/10.1080/00207541003623414

Walancik, M., \& Chmiel, M. (2014). Security as a goal of the state existence-conditions and contexts based on the case of Poland. Forum Scientiae Oeconomia, 2(2), 5-15. 
van der Veeken, D. J. M., \& Rutten, W. G. M. M. (1998). Logistics Service Management: Opportunities for Differentiation. The International Journal of Logistics Management, 9(2), 91-98. https://doi.org/10.1108/09574099810805861

Wong, C. Y., \& Karia, N. (2010). Explaining the competitive advantage of logistics service providers: A resourcebased view approach. International Journal of Production Economics, 128(1), 51-67. https://doi.org/10.1016/J.IJPE.2009.08.026

Wu, Y. (2012). A dual-response strategy for global logistics under uncertainty: a case study of a third-party logistics company. International Transactions in Operational Research, 19(3), 397-419. https://doi.org/10.1111/j.14753995.2011.00839.x

Yeung, H. Y. J., Selen, W., Sum, C., \& Huo, B. (2006). Linking financial performance to strategic orientation and operational priorities. International Journal of Physical Distribution \& Logistics Management, 36(3), $210-230$. https://doi.org/10.1108/09600030610661804

Zielińska, A., Prudzienica, M., Mukhtar, M., \& Mukhtarova, K. (2016). The examples of reverse logistics application in inter-sector partnerships - good practices. Journal of International Studies, 9(3), 279-286. https://doi.org/10.14254/2071-8330.2016/9-3/22 